\title{
Perception of Store Owners on Marketing of Processed Peanut Products in Central Java
}

\author{
Amron Amron \\ Dian Nuswantoro University, Semarang, Indonesia
}

\begin{abstract}
The aim of this study was to examine the relationship between the variables of product, promotion, and distribution with buying decisions on processed peanut food products in Central Java, Indonesia. This study was different from previous studies because it viewed at the marketing of processed peanut products from the point of view of shop owners who bought various brands of processed peanut food products for resale to endusers. The results of this study validate the strong relationship of the three independent variables with buying decision. Surprisingly, however, this study found that product variable had greater effect than the other two variables with a higher level of significance. This research suggest to company managements to always improve product quality, promotion, and distribution in their promotion program. However, in the implementation, corporate managements should pay greater attention to product quality. It is in line with the findings of the research that product variable has a greater effect compared with promotion and distribution variables.
\end{abstract}

Keywords: Food Product, Promotion, Distribution, Buying Decision

\section{INTRODUCTION}

Indonesia is a country with tropical region that strongly supports the processed peanut food industry. It is in line with the vast area of agriculture supported by dry and rainy seasons so that peanut plants thrive in Indonesia. As a result, in Indonesia, various companies provide processed peanut products with various brands, such as Garuda brand, Dua Kelinci brand, Sukro brand, Mayasi brand, Katom brand, and Iyes brand. From 2013 to 2015, the peanut brand of Garuda became a processed peanut food product that always ranked the first with the top brand score of 60.9 in 2013, and then it reacherd 61.4 and 56.6 in 2014 and 2015 respectively (TBI, 2015). The data shows that Garuda's top brand score declined. The top brand score is the level of brand acceptance of a product in the viewpoint of consumers (TBI, 2015). The other competitor, such as Dua Kelinci brand, had a fluctuative top brand score of 28 in 2013, 22.0 in 2014, and 23.4 in 2015. Then, the other brands, such as Mayasi, Sukro, and Iyes, fluctuated between the scores from 1.8 to 7.3 (TBI, 2015). This phenomenon showed that the competition of processed peanut products among the brands in the market was very tight. Therefore, Further research is required on the factors influencing the buying decision of peanut food products.

Buying decision is a selection of two or more alternative options to consumer purchases (Lee and Tse, 1994; Lusk and Biggeman, 2009;). Consumers have a choice between making a buying and not making a buying or the option of using time, and then consumers are in a position to make a decision (Wang et al., 2001). Conversely, if the consumers have no alternative to choose and are really forced to make certain purchases or take certain actions, the only one with no other choice is not a decision (Wang et al., 2001; Amron, 2017). Many factors can influence the buying decision of a particular product. According to Lusk and Biggeman (2009) and Tirelli 
and Martínez-Ruiz (2014), they state that product, promotion and distribution are the factors that can influence buying decisions.

In relation with the description above, this research analyzed the effect of product, promotion and distribution on consumer's buying decision of processed peanut product by taking the location in Central Java, Indonesia. Central Java is chosen as the research location because the majority of processed peanut food producers operating in Indonesia are located in Central Java. The respondents of this study were the shop owners who bought processed peanut products to the producers in Central Java. The shop owners were selected as the respondents because the sales position of processed peanut food products is currently dominated by the stores with very strong enduser basis in Central Java.

The benefits of this research were aimed at the managements of processed peanut food producers, especially in developing marketing promotion strategy. This research is also useful for marketers in increasing sales at retailer level.

\section{Consumer's Decision}

\section{THEORETICAL BACKGROUND}

Buying decision is a selection of two or more alternative choices or more by consumers in buying (Sirgy, 1982). Buying decision is consumer's decision regarding the preferences of brands in the set of choices (Doran, 1984. Consumers will be involved in the intensive buying decision process, especially against the purchases with the criteria of expensive, risky, rarely purchased, and involving profit and loss.

Buying behavior is affected by dissonance that occurs when consumers are heavily involved in expensive, rarely done, or risky purchases, but only sees little difference between brands. The other researchers, such as Kang and Kim (1998), mention that buying behavior is influenced by consumer habits. The behavior of habit buying occurs in a state of low consumer engagement and little brand difference (Baruk and Iwanicka, 2015; Doran, 1984; Amron and Usman, 2016) . Consumers have little involvement in this product category, and they just go to the stores and take one brand. If they continue to take the same brand, this is merely a habit rather than a strong loyalty to a brand (Doran, 1984; Kang and Kim, 1998; Amron and Mahmud, 2017). Such consumers have low involvement with mostly cheap products which are often purchased.

According to Kang and Kim (1998) and Baruk and Iwanicka (2015), buyers will pass through learning process. Firstly, it develops a belief about a product, and then attitude and making appropriate buying choices. The marketers of products requiring high involvement should understand information collection and evaluation behavior engaged by the consumers with high involvement. Marketers need to help consumers learn about product attributes and the relative importance of the attributes (Baruk and Iwanicka, 2015).

\section{Product on Buying Decision}

Product is something that companies offer to consumers to meet the needs and to satisfy consumers (Wang et al., 2001). Product is also defined as anything that can be offered to the market to satisfy the wants or needs of consumers (Lee and Tse, 1994). Marketed products include physical goods, service items, experiences, events, people, places, property, organizations, information, and ideas. Consumers buy more products because of the value contained in the products (Lusk and Biggeman, 2009). If a person needs a product, they firstly imagine the benefits of the product and then consider other factors beyond the benefits. The factors make consumers decide to buy or not (Wang et al., 2001; Lusk and Biggeman, 2009). 
Many studies had been conducted by associating product with buying decision of goods. For example, Tirelli and Martinez-Ruiz (2014) examined the effect of product on food buying decisions in Spain. The study was conducted on 139 international class students at Spanish University. The results showed a positive relationship between product and the food buying decision of the international students. The results of this study are also in line with Lusk and Biggeman (2009) which validated the relationship between product and buying decision of goods. Similarly, the research conducted by Baruk and Iwanicka (2015) strengthened the relationship between product and consumer decisions. Therefore, this research concludes the relationship between product and buying decision on processed peanut food product. Then, the researcher formulated the hypothesis as follows ;

H1: there is a positive effect of price on buying decision in processed peanut food product in Central Java.

\section{Promotion on Buying Decision}

Promotion is communicating information between sellers and potential buyers or others to influence attitudes and behavior (Blattberg et al., 1995; Tan and Bogomolova, 2016). Promotion is company's communication to consumers towards products or services produced in an effort to build a favorable relationship (Wobker et al., 2015; Blattberg et al., 1995). Building a good customer relationship requires more than just developing a good product, attractive product pricing, and providing the product to targeted customers (Blattberg et al., 1995). A company must also communicate its product value proposition to customers, and what is communicated should not be left alone. All forms of communication must be planned and integrated into a carefully integrated marketing communication program. In addition to the importance of establishing and maintaining various types of relationships, good communication is an essential element in company's efforts to build a profitable customer relationship (Wobker et al., 2015). A product that is properly, routinely and intently promoted can influence consumer's buying decisions (Wobker et al., 2015).

Various studies that put promotional variables associated with buying decision had been conducted by researchers. For example, Huang and Yang (2015) examined the effect of promotion in the form of the special discount in Taiwan. The results of their research state that there is a relationship between promotion of buying decisions. The other researchers, such as Wobker et al. (2015), also confirm that there is a relationship between promotion and buying decision. Then, the researcher concluded that there is a relationship between promotion and buying decision.

H2: Promotion is positively associated with the buying decisions of processed peanut food products in Central Java.

\section{Distribution on Buying Decision}

Distribution is any set of companies or individuals participating in a product stream from producers to end users or consumers (Liu et al., 2014; Hammoundi and Hamza, 2015). Distribution is a group of interdependent organizations to help make products or services available for use or consumption by consumers or business users (Luu et al., 2016; Liu et al., 2014). Most manufacturers do not sell their goods directly to end users. They are a group of intermediaries performing various functions and form marketing channel (Liu et al., 2014).

The research that had been conducted by previous researchers found the inter-distribution relationship with the buying decision of goods viewed from various aspects. For example, a study conducted by Luu et al. (2016) examined the distribution of seafood products involving 135 distributors in Vietnam. The results states that there is an effect of distribution on buying decisions. The results of this study were also confirmed by the research of Liu et al. (2014) 
which suggests that there is a positive relationship between distribution and buying decisions. Then, the study established the hypothesis as follows;

H3: Distribution has positive effect on the buying decision of processed peanut food products in Central Java.

\section{METHODOLOGY}

This research used the data instrument of questionnaire to obtain primary data. The questionnaires were divided into two parts; the first part contained the data of respondent's characteristics, and the second part was the list of questions to be filled by the respondents. The researcher spread 110 questionnaires to respondents consisting of the shop owners in Central Java who bought various brands of processed peanut food products from producers who then re-sold to the endusers. The data obtained were tabulated, and then processed using the SPSS. Furthermore, the researcher conducted the analysis and interpretation of the research data.

\section{Respondent's Characteristics}

\section{RESULTS AND DISCUSSION}

A total of 110 questionnaires were distributed to the respondents, but only 104 were declared eligible for further processing. The information obtained from 104 respondents showed that 54 per cent respondents made a business by opening the shops for more than five years and the remaining 46 per cent was under five years. The average monthly incomes from the sales of processed peanut products were above US $\$ 7,500$ (11 per cent), US $\$ .5,000$ up to US $\$ .7,500$ (14 per cent), and the remaining 75 per cent was below US $\$$. 5,000. By sex, 64 per cent of the respondents was male, and the remaining 36 per cent was female.

\section{Validity Test}

The product variable consisted of four indicators with the smallest value of $r$ count of 0.627 and the biggest one of 0.670 . The distribution variable consisting of four indicators shows the smallest $r$ count of 0.490 and the largest one of 0.682 . Furthermore, the distribution variable with five indicators resulted in the smallest figure of 0.557 and the biggest one of 0.773 . The variable of buying decision with four indicators indicated the fact that the smallest $r$ count is 0.508 and the largest one is 0.722 . By using the reference of $r$ table of 0.193 , the validity test results show that the $r$ value of each indicator/ questionnaire is greater than the $r$ table value so that the indicators/ questionnaires used by the variables of product, promotion, distribution and buying decisions are valid as the measuring instruments for the variables.

\section{Reliability Test}

Reliability test was used to measure the reliability of the indicators/ questionnaires as the variable measurement instrument. The consistency of the respondent's answers from time to time when asked the same question indicates the reliability of the indicators/ questionnaires used. The results of the reliability test show that the cronbach's alpha value of each variable is greater than 0.60 , so the indicators/ questionnaires used by product, promotion, distribution and buying decisions are reliable as the variable measuring instruments (see Table 1.).

\section{Normality Test}

The result of kolmogorov smirnov test shows that the sig value of product is 0.144 , promotion of 0.080 , distribution of 0.142 , and buying decision of 0.261 . All sig values of kolmogorov smirnov test are greater $(>)$ than $\alpha=0.05$. It means that the regression model has normal data distribution. 


\section{Heteroscedasticity Test}

Based on the results of the glejser test, it shows that all tested variables are not significant or the probability of significance is greater than $5 \%(0.05)$; product of 0.606 , promotion 0.668 , and distribution of 0.117 . It means that the regression model is free from heteroscedasticity problems.

\section{Multicollinearity Test}

The multicollinearity test results show that between the independent variables (product, promotion and distribution) are not all multicollinearity because, in the the independent variables, the Tolerance value is greater than 0.1 , and the VIF value is below 10 (see Table 2.).

Table 1. Reliability Results

\begin{tabular}{|l|c|c|c|c|}
\hline \multicolumn{1}{|c|}{ Variable } & $\begin{array}{c}\text { Cronbach's } \\
\text { Alpha }\end{array}$ & $><$ & $\begin{array}{c}\text { Reliability } \\
\text { Standard }\end{array}$ & Remark \\
\hline Product & .805 & $>$ & .60 & Reliable \\
\hline Promotion & .794 & $>$ & .60 & Reliable \\
\hline Distribution & .799 & $>$ & .60 & Reliable \\
\hline Buying Decision & .774 & $>$ & .60 & Reliable \\
\hline
\end{tabular}

Source : Processed Primary Data

Table 2. multicollinearity Test Results

Coefficients $^{\mathrm{a}}$

\begin{tabular}{|ll|r|r|}
\hline \multirow{2}{*}{ Model } & \multicolumn{2}{|c|}{ Collinearity Statistics } \\
\cline { 3 - 4 } & & Tolerance & \multicolumn{1}{l|}{ VIF } \\
\hline 1 & Product &, 202 & 4,942 \\
& Promotion &, 175 & 5,703 \\
& Distribution &, 373 & 2,684 \\
\hline
\end{tabular}

a. Dependent Variable: Buying Decision

\section{Source : Processed Primary Data}

\section{Multiple Regression Analysis}

The analytical technique used was multiple regression analysis. The technique was used to recognize the effect between the independent and dependent variables (see Table 3). The results of this study indicate that all independent variables have positive effects on buying decision. The value of sig. obtained is less $(<)$ than $\alpha=0.05$. Then, it proves that all hypotheses of this research are accepted.

Table 3. Multiple Regression Results

Coefficients $^{a}$

\begin{tabular}{|c|c|c|c|c|c|c|}
\hline \multirow{2}{*}{\multicolumn{2}{|c|}{ Model }} & \multicolumn{2}{|c|}{$\begin{array}{l}\text { Unstandardized } \\
\text { Coefficients }\end{array}$} & \multirow{2}{*}{$\begin{array}{c}\text { Standardized } \\
\text { Coefficients } \\
\text { Beta }\end{array}$} & \multirow[b]{2}{*}{$\mathrm{t}$} & \multirow[b]{2}{*}{ Sig. } \\
\hline & & $B$ & Std. Error & & & \\
\hline \multirow[t]{4}{*}{1} & (Constant) &, 730 & ,689 & & 1,062 & ,292 \\
\hline & Product & ,416 & , 105 & ,412 & 3,974 & , 000 \\
\hline & Promotion & ,252 & 110 & ,250 & 2,296 & ,026 \\
\hline & Distribution & ,264 & ,075 & ,254 & 3,563 & ,001 \\
\hline
\end{tabular}

a. Dependent Variable: Buying Decision

Source : Processed Primary Data 


\section{Goodness of Fit Test}

Goodness of Fit test was used to see the accuracy of the regression model in this study. The determination coefficient shows the Adjusted $\mathrm{R}$ Square value of 0.774 . These results indicate that product, promotion and distribution are able to explain the buying decision of 77.4 per cent, while by 22.6 per cent of them is explained by the other variables which are not discussed in this study.

\section{F- Test}

F-Test was used to prove the significant effect of product, promotion and distribution on buying decisions simultaneously. The research test results show simultaneous effect of product, promotion and distribution on buying decision at 118.484 with sig, 0.000 . The sig value obtained is less $(<)$ of $\alpha=0.05$. Then, product, promotion and distribution have the effect on buying decision simultaneously.

\section{DISCUSSION}

The aim of the study was to examine the effect of product, promotion, and distribution on consumer's buying decision of processed peanut food products in Central Java, Indonesia by using the sample of the shop owners who bought products from various brands and companies for resale to endusers. The results found that product and promotion have a positive and significant effect on buying decision as well as distribution with the same effect. However, of the three independent variables, the variable of product quality has the greatest effect compared to the other variables with the significance level reaching 0.000 (see table 3).

The effect of the variable of product on buying decision is in a positive direction meaning that any product improvement will improve consumer's buying decision of processed peanut food products in Central Java. Product is something that manufacturers can offer to be noticed, requested, sought, purchased, used, or consumed by the market as the fulfillment of the needs or desires of the relevant market (Lee and Tse, 1994; Wang et al., 2001). This research is in line with the studies of Tirelli and Matinez-Ruiz (2014) and Baruk and Iwanica (2015) which state that there is a positive relationship between product and buying decision. However, this study has differences with previous research viewed from the packaging side. The majority of respondents believed that packaging is very important in deciding the purchase. The packaging impressed to be luxurious will show a classy brand. The product packaging shows the product quality in the packaging. Packaging also shows the brand class of products sold. Therefore, this research suggests company managements to keep the quality of packaging so that the brand image in the eyes of consumers increases. Then, it is able to stimulate consumers to increase product purchases.

Positive effect also occurs on promotion variable on buying decision with the significance level of 0.026 . The results prove the hypothesis that promotion has a positive effect on buying decisions can be accepted. This result can also be interpreted that any promotional enhancement will increase consumer's buying decision of processed peanut food products in Central Java. Blattberg et al. (1995) and Wobker et al. (2015) state that promotion is a marketing activity that seeks to disseminate information, to influence and remind target markets of the company and its products to be willing to accept, buy and be loyal to the products offered by the company. This study supports the previous studies conducted by Huang and Yang (2015) and Wobker et al. (2015). In particular, this study has differences with previous studies in looking at the promotional variable of the respondents. The respondents of this study saw that the sponsor through TV, especially in sports events such as football, is very important compared with other promotional programs. Therefore, the researcher suggests to the company's managements to increase promotion through increasing the frequency of 
impressions on TV, especially interesting events such as soccer sport events. Then, it can boost product sales quickly and significantly. The more frequent the product appears in the promotion program, the higher the quantity and quality of the product sales.

The other finding of this study suggests that distribution is able to influence buying decision in a positive direction. Then, the hypothesis that distribution has a positive effect on buying decision is proven. This result can also mean that any increase in distribution will improve consumer's buying decision of processed peanut food products in Central Java. Distribution is a marketing activity that seeks to smoothen and facilitate the delivery of goods and services from producers to consumers so that its use is in accordance with the needs (Hammoundi and Hamza, 2015). The results of this study are in line with Liu et al. (2014) and Luu et al. (2016). However, this study has differences with previous studies. The study found that the respondents felt that product variability plays a very important role compared to other indicators. The availability of processed peanut products consisting of many varieties and packaging as well as easy to obtain is very important for the respondent. Therefore, this research suggests to company managements to consider the distribution of goods simultaneously. Complete distribution includes each type of product simultaneously to the market will be able to increase sales.

\section{Managerial Implications}

The managerial implication in this study is based on the main findings of this research. The variables of product, promotion and distribution were able to show their roles in influencing buying decisions in a positive direction. It is suggested to company managements to pay attention to the three variables, in terms of product variables, by making attractive packaging and luxurious impression because, in the eyes of consumers, packaging is identical to brand image. In terms of the variables of promotion and distribution, company managements are suggested to increase promotion through TV accompanied by building means of distribution of goods which is able to provide complete product variations in easily accessible places.

\section{CONCLUSION}

The aim of this study was to examine the effects of product, promotion, and distribution on buying decision. The findings confirmed the strong relationship between the three independent variables to buying decision. In terms of strong relationship of product variable with buying decision, this study suggests company managements to improve the packaging quality of processed peanut food products because the respondents believed that luxurious packaging is identical with high brand image. Meanwhile, in terms of the strong relationships between promotion and distribution on buying decision, this research suggests company managements to increase the frequency of ad impressions through TV accompanied by complete product distribution. In particular, this research suggests to marketers that marketing does not only highlight the strength of promotion and distribution, but it should have more emphasis on the product. According to the results of this study, product has a greater effect than promotion and distribution

\section{References}

Amron, A. (2017), "Marketing Challenge of Import Insurance Product in Indonesia", Advance Science Letters, Vol. 3 No. 8, pp. 7243-7245.

Amron, A. \& Mahmud, M. (2017), “Developing Marketing Strategy in Property Insurance Business”. International Business Management, Vol. 11 No. 1, pp. 177-182.

Amron, A and Usman, U. (2016), "Customer Satisfaction in the Marketing of Inland Transit Insurance Service”. International Journal of Applied Business and Ecomonic Research, Vol. 14 No. 12, pp. 8311-8321. 
Baruk, A. I. and Iwanicka, A. (2015) "Polish final purchasers' expectations towards the features of dairy product packaging in the context of buying decisions", British Food Journal, Vol. 117 No.1, pp.178-194.

Blattberg, R. C., Briesch, R., and Fox, E. J. (1995), "How Promotions Work", Marketing Science, 14(No. 3, Part 2), G122-G132.

Doran, K.B. (1994), "Exploring cultural differences in consumer decision making: Chinese consumers in Montreal”, Advances in Consumer Research, Vol. 21, pp. 318-322.

Hammoundi, A. and Hamza, O. (2015), "Food safety on domestic markets of developing countries: how to improve the contribution of export and domestic supply chain?", International Journal of Bussiness and Mangement, Vol. 10 No. 5, pp. 20-43.

Huang, W. and Yang, C. (2015), "Buy four get $30 \%$ off: how consumers respond to missing a quantity discount", European Journal of Marketing, Vol. 49 No. 7/8, pp.1326-1342.

Kang, J. and Kim, Y. (1998), “Ethnicity and acculturation: influences on Asian American consumers' purchase decision making for social clothes", Family and Consumer Sciences Research Journal, Vol. 27 No. 1, pp. 91-117.

Lee, W. and Tse, D.K. (1994), “Changing media consumption in a new home: acculturation patterns among Hong Kong immigrants to Canada", Journal of Advertising, Vol. 23 No. 1, pp. 57-70.

Liu, Y., Zhang, Q. and Li, Q. (2014), "A research on mechanisms and countermeasures of the food safety incidents occuring on food supply chain", Journal of Service Science and Management, Vol. 7 No. 4, pp. 337-345.

Lusk, J.L. and Briggeman, B. (2009), “Food values”, American Journal of Agricultural Economics, Vol. 91, pp. 184196.

Luu, P., H., Dunne, M., P., Pearse, W. and Davies, B. (2016) "Seafood safety compliance with hygiene regulations within Vietnamese domestic distribution chains", British Food Journal, Vol. 118 Issue: 4, pp.777794.

Sirgy, M.J. (1982), "Self-concept in consumer behavior: a critical review", Journal of Consumer Research, Vol. 9, pp. 287-300.

Tan, P., J. and Bogomolova, S. (2016) "A descriptive analysis of consumer's price promotion literacy skills", International Journal of Retail \& Distribution Management, Vol. 44 No. 12, pp.1223-1244.

TBI. (2015), Top brand Indonesia fase 1. http://www.topbrand-award.com/top-brand-survey/survey-result/topbrand-index-2015. (accessed 1 October 2015).

Tirelli, C. and Martínez-Ruiz, M, P. (2014),"Influences of product attributes on sojourners' food purchase decisions", British Food Journal, Vol. 116 No. 2 pp. 251 - 271.

Wang, C.C.L., Chan, A.K.K. and Chen, Z.X. (2001), "Segment intenders and non-intenders in China's property market: a hybrid approach", Journal of Consumer Marketing, Vol. 18 No. 4, pp. 319-331.

Wobker, I., Eberhardt, T., and Kenning, P. (2015), "Consumer confusion in German food retailing: the moderating role of trust", International Journal of Retail \& Distribution Management, Vol. 43 No. 8, 752-774. 